\title{
Estimation of Cosmic Effect on Background Nuclear Radiation
}

\author{
Ibikunle S. B. ${ }^{1}$, Ibikunle B. C. ${ }^{1}$, Akinmoju C. ${ }^{1}$ \\ ${ }^{1}$ Department Of Physics, The Federal University of Technology, P. M. B. 704, Akure, Ondo State. Nigeria. \\ Corresponding Author: Ibikunle S. B.
}

DOI: https://doi.org/10.52403/ijrr.20220310

\begin{abstract}
The effect of cosmos on background nuclear radiation has been estimated with altitude on Idanre hill using the rad scanner model $500 \mathrm{VBR}$. Five readings were taken in order to ensure accuracy and reliability of the result. The mean absorbed dose rate in air for ground, middle and top of the hill were estimated to be $322.67 \pm 35.80, \quad 353.72 \pm 37.79$ and $457.88 \pm$ $40.30 \mathrm{nGy} \mathrm{h}^{-1}$ respectively. The absorbed dose rate and the effective dose equivalent increases with height which is an indication of nuclear radiation enhancement by the cosmos. The mean outdoor annual effective dose equivalent was obtained as $0.40 \pm 0.05,0.43 \pm 0.08$ and $0.56 \pm 0.06$ $\mathrm{mSv} \mathrm{y}^{-1}$ respectively. The mean absorbed dose rate and the mean outdoor annual effective dose equivalent from different heights are higher than the world average of $59^{\mathrm{nGy}}{ }^{\mathrm{h}-1} \mathrm{r}$ and $0.07 \mathrm{mSv}$ $\mathrm{y}^{-1}$ respectively and the World Health Organization recommendation of $0.1 \mathrm{mSv} \mathrm{y}^{-1}$, but lower than the International Commission on Radiological Protection recommendation of 1.0 $\mathrm{mSv} \mathrm{y}^{-1}$. The estimated excess lifetime cancer risk $1.83 \times 10^{-3}$ is higher than the world average value of $2.9 \times 10^{-4}$. This implies a highly significant radiation health risk in the area most predominantly as the height increases and the cosmic effect heightened up.
\end{abstract}

Keywords: Cosmos; Background nuclear radiation; Rad scanner; Effective dose; Cancer risk.

\section{INTRODUCTION}

Background radiation abounds everywhere in our environment since the earth was formed. Background radiation is emitted from both natural and human made radionuclides. Some naturally occurring radiation emanate from the atmosphere as a result of radiation from outer space, while some come from the earth, and even our bodies as a result of radionuclides in the food and water we ingest or the air we breathe. Additionally, human made radiation enters our environment from consumer products, activities such as medical procedures, and nuclear power plants. The largest source of human made radiation exposure or dose is from medical diagnosis and treatment (NCRP 2009)

Cosmic radiation consist of very energetic particles, mostly protons, which bombard the Earth from outer space. It is more intense at higher altitudes than at sea level where the Earth's atmosphere is most dense and gives the greatest protection (Sharma, 2008).

The high-energy component of cosmic radiation decreases exponentially and it is a function of the cumulative mass penetrated, which is perpendicular to the surface of the rock (Gosse and Phillips, 2001). The length of attenuation, which is the thickness of a slab of material, is required to attenuate the intensity of the cosmic-ray flux due to scattering and absorption processes. The attenuation length varies with altitude and latitude, because the energy spectrum is changed by geomagnetic field and the atmosphere (Gosse and Phillips, 2001). The coefficient of attenuation is expressed in terms of mass length unit $\left(\mathrm{g} \mathrm{cm}^{-2}\right)$, which is a factor of 
total mass traversed and is therefore a function of the material's density. (Balco, 2011; Balco et al., 2008; Gosse and Phillips, 2001).

The sample thickness is an important parameter in the calculation of an exposure age, because production by spallation within the rock is assumed to have an exponential depth-dependence with a single attenuation length (Balco et al., 2008).

\section{METHODOLOGY}

Measurement where taken at different height and locations on Idanre hills for the determination of the background nuclear radiation with height. Idanre hills, are located in the Ondo State, Southwestern Nigeria. It consists of high plain with spectacular valleys interspersed with inselbergs of about 3,000 ft above sea level. Its physical attributes include Owa's Palace, Shrines, Old Court, Belfry, Agboogun foot print, thunder water, burial mounds and plain grounds. It also has diverse and variegated eco-systems of flora and fauna. Idanre hills contains very important biophysical and land form features whose interaction with the physical features created an enduring cultural landscape within the setting.

According to history, Idanre people used to live high up on the hills, in an area which is now known as old Oke-Idanre, a major attraction at Idanre Hills Tourist Center. This area consists of old and dilapidated mud buildings roofed in rustbrown iron sheets, set on well laid-out streets. Attesting to the architectural taste of the old Idanre people, the old magistrate court, the first primary school, the Oba's palace and the market square hold their original place and location at Odeja Village, Old Oke-Idanre.

It was recorded that the old Idanre people descended the hills and resettled at the present foothill location of Idanre town. It has also been noted that every street in the new Idanre town has a replica at the OldOke Idanre and every family has been allowed to retain ownership of their family houses at the Old enclave. The people are known to be very proud of their heritage in culture and history and these have never ceased to draw tourists of all ramifications to the hilltop site. However, in order to reach the hilltop village site, one will have to ascend 653 steps that leads up the hills.

\section{Measuring Instrument}

The instrument used for detecting and also measuring theses radiations is the rad scanner model 500VBR. This can detect gamma rays, alpha and beta particles by the pulse mode of operation by flashing the red LED for each particle detected. In this mode the detector measures the number of nuclear particles detected that minute in counts per minute and when this exceeds 1095 counts per minute or $10 \mu \mathrm{Gy} \mathrm{h}^{-1}$. An indication of a continuous tone is given. When an ionizing particle enters the counter, ionization takes place and a few ions are produced. If the applied potential difference is strong enough, these ions are multiplied by further collisions; the movement of electrons is what generates the current impulse which is later amplified so that single particles can be registered. The detector can also give cumulative counts in counts per hour. In this mode, the number of counts over a longer period can be collected and displayed on the screen.

\section{Research Procedure}

At every location in the given choice of site, the Rad scanner is switched on, the readings that appears immediately on the LCD of the Rad scanner is not taken and recorded, rather the measurement of the background nuclear radiation of that environment starts counting after one minute in that environment. The process of recording per minute continues for at least five minutes using the radiation scanner. After this process, the radiation scanner is switched off.

\section{Dosimetric Quantities}

Dose is the measure of energy absorbed in matter; it is used in dosimetry 
for energy absorbed per unit mass of the material. It may be measured in Joules/kilogram and represented by the equivalent SI unit, gray (Gy).

$D=\frac{d_{E}}{d_{m}}$

Where $d_{E}$ is the mean energy imparted on a volume element by an ionizing radiation and $\mathrm{d}_{\mathrm{m}}$ is the mass of the volume element.

Dose Equivalent: This term specifies the biological effect of a particular type of radiation. It's unit is Sievert (Sv). The dose equivalent is the product of the absorbed dose (D) and the quality factor (Q.F).

Quality Factor: This is the relative biological effectiveness of the radiation type.

Effective Dose: This is the radiation quantity that takes into account the radio sensitivity of individual organ.

A measure of the radio sensitivity for the different tissues is called the tissueweighing factor $\mathrm{W}_{\mathrm{T}}$ given in the Table 1 .

$H_{E}=\sum W_{T} H_{T}$

Collective Effective Dose: The total impact of the radiation exposure due to a given practice or source depends on the number of individuals that are exposed as well as the dose received. The collective effective dose $S_{E}$ to any group is the summation of the products of the mean effective dose $\mathrm{H}_{\mathrm{E}}$ in various sub-groups of the exposed people and the number $\mathrm{N}_{\mathrm{i}}$ of individual given as:

$\mathrm{S}_{\mathrm{E}}=\sum N_{i} H_{E}(\mathrm{Man}-\mathrm{Sv}) \quad 3$

This risk of having different health effects on an individual within a given population is given as:

$$
\mathrm{R}=\sum P_{i} \quad 4
$$

Where $\mathrm{P}_{\mathrm{i}}$ is the probability that the individual will have an effect $i$.
For a homogenous population of $\mathrm{N}$ individuals, the collective health detriment $\mathrm{G}$ is given as:

$$
\mathrm{G}=\mathrm{N} \sum P_{i} g_{i}
$$

Where $g_{i}$ is the severity factor of the effect $i$. The collective health detriment $G$ on a population of $\mathrm{N}$ people can be written in terms of the collective dose $\mathrm{S}_{\mathrm{E}}$ given as:

$\mathrm{G}=\mathrm{R}_{\mathrm{T}} \mathrm{S}_{\mathrm{E}} \quad$ (Man)

6

where $R_{T}$ is a constant of proportionality called the Total Risk Factor. The Risk Factor for different tissues is given in Table 1 above.

Table 1: The weighing and risk factors for different tissues (ICRP, 1990)

\begin{tabular}{|l|l|l|}
\hline Organ & $\begin{array}{l}\text { Weighing factor } \\
\left(\mathbf{W}_{\mathrm{T}}\right)\end{array}$ & $\begin{array}{l}\left.\text { Risk factor } \mathbf{x} \mathbf{( 1 0}^{-\mathbf{3}}\right) \\
\mathbf{S v}^{-\mathbf{1}}\end{array}$ \\
\hline Gonad & 0.25 & 4.00 \\
\hline Breast bone & 0.15 & 2.50 \\
\hline $\begin{array}{l}\text { Red } \\
\text { marrow }\end{array}$ & 0.12 & 2.00 \\
\hline Lung & 0.12 & 2.00 \\
\hline Thyroid & 0.03 & 0.50 \\
\hline Bone & 0.03 & 0.50 \\
\hline Remainder & 0.30 & 5.00 \\
\hline Total & 1.00 & 16.50 \\
\hline
\end{tabular}

\section{RESULT}

Table 2: The average count per minute of the Ground Region

\begin{tabular}{|l|l|l|l|l|l|l|}
\hline Locations & \multicolumn{5}{|l|}{ Time(Mins) } & \multicolumn{1}{l|}{$\begin{array}{l}\text { Average } \\
\text { Cpm }\end{array}$} \\
\hline \multirow{3}{*}{$\begin{array}{l}\text { Ground } \\
\text { Region }\end{array}$} & T1 & T2 & T3 & T4 & T5 & (27 \\
\cline { 2 - 6 } & 75 & 27 & 16 & 24 & 25 & 33.4 \\
\cline { 2 - 6 } & 83 & 24 & 14 & 15 & 23 & 31.8 \\
\cline { 2 - 6 } & 87 & 29 & 33 & 30 & 25 & 40.8 \\
\hline
\end{tabular}

\begin{tabular}{|c|c|c|c|c|c|c|}
\hline Locations & \multicolumn{5}{|c|}{ Time (Mins) } & \multirow{2}{*}{$\begin{array}{l}\text { Average } \\
\text { Cpm }\end{array}$} \\
\hline \multirow{7}{*}{ Middle Region } & $\mathrm{T} 1$ & $\mathrm{~T} 2$ & T3 & $\mathrm{T} 4$ & T5 & \\
\hline & 45 & 32 & 33 & 41 & 26 & 35.4 \\
\hline & 47 & 31 & 27 & 34 & 28 & 32.4 \\
\hline & 84 & 41 & 23 & 22 & 31 & 40.2 \\
\hline & 51 & 27 & 26 & 22 & 27 & 30.6 \\
\hline & 75 & 41 & 34 & 28 & 40 & 43.6 \\
\hline & 96 & 41 & 29 & 45 & 40 & 50.2 \\
\hline
\end{tabular}

Table 3: The average count per minute of the Middle Region.

Table 4: The average count per minute of the elevated region

\begin{tabular}{|l|l|l|l|l|l|l|}
\hline Locations & \multicolumn{5}{|l|}{ Time (Mins) } & $\begin{array}{l}\text { Average } \\
\text { Cpm }\end{array}$ \\
\hline \multirow{3}{*}{ Elevated Region } & $\mathrm{T} 1$ & $\mathrm{~T} 2$ & $\mathrm{~T} 3$ & $\mathrm{~T} 4$ & $\mathrm{~T} 5$ & \\
\cline { 2 - 7 } & 78 & 35 & 42 & 38 & 30 & 44.6 \\
\cline { 2 - 7 } & 83 & 50 & 43 & 60 & 41 & 55.4 \\
\cline { 2 - 7 } & 88 & 47 & 51 & 26 & 40 & 50.4 \\
\hline
\end{tabular}

\begin{tabular}{|c|c|c|c|c|c|c|c|}
\hline Locations & \multicolumn{5}{|c|}{ Time (Mins) } & \multirow{2}{*}{$\begin{array}{l}\text { Average } \\
\text { Cpm }\end{array}$} & \multirow{2}{*}{ Absorbed Dose Rate ( nGy h ${ }^{-1}$ ) } \\
\hline \multirow{4}{*}{$\begin{array}{l}\text { Ground } \\
\text { Region }\end{array}$} & $\mathrm{T} 1$ & $\mathrm{~T} 2$ & T3 & $\mathrm{T} 4$ & T5 & & \\
\hline & 75 & 27 & 16 & 24 & 25 & 33.4 & 305.02 \\
\hline & 83 & 24 & 14 & 15 & 23 & 31.8 & 290.41 \\
\hline & 87 & 29 & 33 & $30^{\prime}$ & 25 & 40.8 & 372.60 \\
\hline \multicolumn{6}{|l|}{ Mean } & 35.33 & 322.67 \\
\hline \multicolumn{6}{|c|}{ Standard Deviation } & 4.80 & 35.80 \\
\hline
\end{tabular}

Table 5: The Absorbed Dose Rate for Ground Region 


\begin{tabular}{|c|c|c|c|c|c|c|c|}
\hline Locations & \multicolumn{5}{|c|}{ Time (Mins) } & \multirow{2}{*}{$\begin{array}{l}\text { Average } \\
\text { Cpm }\end{array}$} & \multirow[t]{2}{*}{ Absorbed Dose Rate $\left({ }^{\text {nGy h-1 }}\right)$} \\
\hline \multirow{7}{*}{ Middle Region } & $\mathrm{T} 1$ & $\mathrm{~T} 2$ & T3 & $\mathrm{T} 4$ & T5 & & \\
\hline & 45 & 32 & 33 & 41 & 26 & 35.4 & 323.28 \\
\hline & 47 & 31 & 27 & 34 & 28 & 32.4 & 295.89 \\
\hline & 84 & 41 & 23 & 22 & 31 & 40.2 & 367.12 \\
\hline & 51 & 27 & 26 & 22 & 27 & 30.6 & 279.45 \\
\hline & 75 & 41 & 34 & 28 & 40 & 43.6 & 398.17 \\
\hline & 96 & 41 & 29 & 45 & 40 & 50.2 & 458.44 \\
\hline \multicolumn{6}{|l|}{ Mean } & 38.73 & 353.72 \\
\hline \multicolumn{6}{|c|}{ Standard Deviation } & 6.76 & 37.79 \\
\hline
\end{tabular}

Table 7: The Absorbed Dose Rate for Elevated Region

\begin{tabular}{|c|c|c|c|c|c|c|c|}
\hline Locations & \multicolumn{5}{|c|}{ Time (Mins) } & \multirow{2}{*}{$\begin{array}{l}\text { Average } \\
\text { Cpm }\end{array}$} & \multirow{2}{*}{$\begin{array}{l}\text { Absorbed Dose Rate ( }{ }^{\text {nGy }} \text { h-1 } \\
\text { r) }\end{array}$} \\
\hline \multirow{4}{*}{ Elevated Region } & $\mathrm{T} 1$ & $\mathrm{~T} 2$ & T3 & $\mathrm{T} 4$ & T5 & & \\
\hline & 78 & 35 & 42 & 38 & 30 & 44.6 & 407.3 \\
\hline & 83 & 50 & 43 & 60 & 41 & 55.4 & 505.93 \\
\hline & 88 & 47 & 51 & 26 & 40 & 50.4 & 460.27 \\
\hline \multicolumn{6}{|l|}{ Mean } & 50.13 & 457.88 \\
\hline \multicolumn{6}{|l|}{ Standard Deviation } & 4.41 & 40.30 \\
\hline
\end{tabular}

\section{Absorbed Dose Rate}

The absorbed dose rate, which is the amount of energy deposited per unit of weight of human tissue, also it a measure of medium of ionization radiation over a period of time. For each town was calculated by converting the average measurement values obtained from the rad scanner in Count per minute $(\mathrm{Cpm})$ in each town to Nano Grey per hour $\left(\mathrm{nGy} \mathrm{h}^{-1}\right)$. This was done by using the equation below:
Absorbed Dose rate in Air $\left(\mu \mathrm{Gy} \mathrm{h}^{-1}\right)=$ AverageCpmx10 $\mu G \mathrm{yhr}^{-1}$ $1095 \mathrm{Cpm}$

\section{General Background Radioactivity Measurement of the Study Area}

From the result presented in tables 5 to table 7 and figure 1 , the elevated region has the highest absorbed dose rate $50.13 \pm 4.41$ followed by the middle region $38.733 \pm 6.76$. While the lowest absorbed dose rate was at the ground region $35.3 \pm 4.80$.

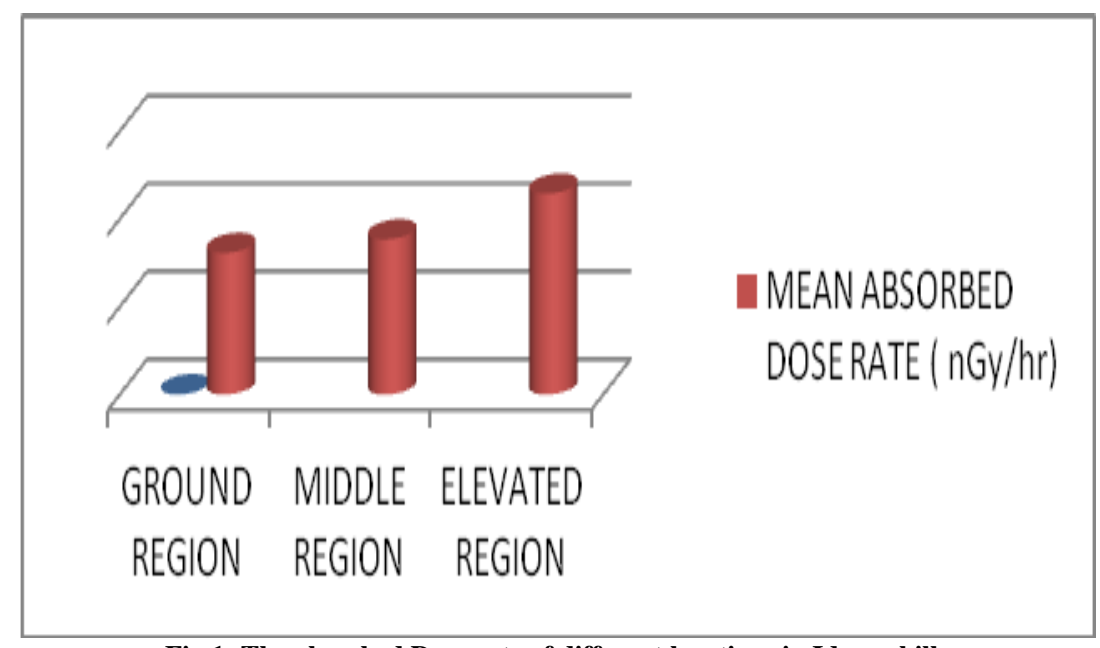

Fig 1: The absorbed Dose rate of different locations in Idanre hill.

Background Radioactivity Measurement on Idanre Hill

The result of background radioactivity measurement as presented in Table 2 to 4 and figure 1 shows that the elevation region has the highest Idanre has the background nuclear radiation. The mean absorbed dose rate in air for the elevation region is given as $457.88 \pm 40.30 \mathrm{nGyh}^{-1}$. This value is higher than the world average value of $55 \mathrm{nGyh}^{-1}$ (UNSCEAR 2008). The high background nuclear radiation in Idanre hill could be as a result of the presence of rocks which is predominant all over the 
entire area. The presence of rock phosphate, which is characterized by nuclear activity, is a major factor for enhanced radioactivity level in the area. Also it might have been affected by other mineral deposit such as sheet mica, lithium minerals, gemstones which are mostly found in igneous rock.

\section{Outdoor Effective Dose Equivalent}

To calculate the outdoor effective dose equivalent in any environment, two factors are to be considered which are;

\section{The conversion factor:}

This gives the human dose equivalent (Sv/yr) from the absorbed dose rate in air $(\mathrm{Gy} / \mathrm{hr}$.). This factor has been recommended by the United Nation Scientific Committee on the Effects of Atomic Radiation (UNSCEAR, 2008) as $0.7 \mathrm{~Sv} / \mathrm{Gy}$.

That is $1 \mathrm{~Gy}=0.7 \mathrm{~Sv}$

\section{ii. The Occupancy factor.}

This gives the amount of time or number of hours a person is exposed to outdoor radiation. this factor has been recommended by the United Nation Scientific Committee on Effects of Atomic Radiation(UNSCEAR, 2008) as 0.2 factor for an urban area, hence an average person should spent 4.8 hours outdoor daily in an urban area. While 0.3 factor for rural area, hence an average person in a rural area should spent 7.2 hours outdoor daily.

The mean Outdoor Effective Dose Equivalent (OEDE) for Idanre hill Ondo State is calculated thus: OEDE $\left(\mathrm{Svy}^{-1}\right)=$ Conversion factor $(0.7 \mathrm{~Sv} / \mathrm{Gy})$ x Occupancy factor (0.2/0.3 (number of hrs/day) x 365.25 days per year x Mean Absorbed Dose Rate in Air $\left(\mathrm{nGyhr}^{-1}\right)$

Table 8: The equivalent outdoor effective dose rate from different locations in Idanre hill

\begin{tabular}{|l|l|l|l|}
\hline Locations & $\begin{array}{l}\text { Average Count per Minute } \\
(\mathbf{C} / \text { Min) }\end{array}$ & $\begin{array}{l}\text { Mean Absorbed Dose Rate (nGy } \\
\mathbf{h}^{-\mathbf{1}} \mathbf{)}\end{array}$ & $\begin{array}{l}\text { Mean Outdoor Effective Dose Equivalent } \\
(\boldsymbol{\mu S v} / \mathbf{y})\end{array}$ \\
\hline Ground Region & $35.30 \pm 4.80$ & $322.68 \pm 35.80$ & $395.73 \pm 53.77$ \\
\hline Middle Region & $38.73 \pm 6.76$ & $353.73 \pm 36.79$ & $429.35 \pm 82.16$ \\
\hline $\begin{array}{l}\text { Elevated } \\
\text { Region }\end{array}$ & $50.13 \pm 4.41$ & $457.88 \pm 40.30$ & $555.71 \pm 59.91$ \\
\hline
\end{tabular}

\section{Excess Lifetime Cancer Risk (ELCR)}

ELCR is employed to calculate or estimate the increased risk of cancer as a result of a lifetime exposure to an agent by ingestion or inhalation. ELCR is usually used to quantitatively evaluate the effects of prolong exposure to the $\gamma-$ radiation associated with the measured natural occurring radionuclides based upon calculated values of AEDE, excess lifetime cancer risk (ELCR) is calculated using equation 8:

\section{ELCR = OEDE $x$ Average duration of life} (DL) $x$ Risk Factor 8

The average life duration is 70 years and ELCR is measured in Sievert. The Risk Factor is the cancer risk per Sievert. For low dose stochastic background radiation, ICRP 103 suggested the value of 0.057 for public exposure. (ICRP, 2007)

The excess lifetime lancer risk at the elevated region has the highest value. This goes on to buttress the point stated earlier, that those living at the elevated region has the highest chances of exposure to background radiation. Furthermore, mean excess lifetime cancer risk due to background radiation calculated as (1.83) $\mathrm{x}$ $10^{-3}$ is about 6.8 times higher than the world average of $0.29 \times 10^{-3}$. This value $(0.803 \times$ $10^{-3}$ ) is higher than the estimated ELCR values at Ota (Oyeyemi et al, 2017) and Itagunmodi (Ademola et al., 2014) of 0.635 $\mathrm{x} 10^{-3}$ and $0.324 \times 10^{-3}$.

Table 9: The excess life time cancer risk from different locations in Idanre hill

\begin{tabular}{|c|c|c|c|}
\hline Locations & $\begin{array}{lr}\text { Mean } & \text { Outdoor } \\
\text { Effective } & \text { Dose } \\
\text { equivalent } & \left(\mathrm{mSv} \mathbf{y}^{-}\right. \\
\left.{ }^{1} \mathbf{r}\right) & \end{array}$ & $\begin{array}{l}\text { Risk } \\
\text { factor }\end{array}$ & $\begin{array}{l}\text { Excess Life } \\
\text { Time Cancer } \\
\text { risk }\left(* 10^{-3}\right)\end{array}$ \\
\hline $\begin{array}{l}\text { Ground } \\
\text { Region }\end{array}$ & 0.395 & 0.057 & 1.57 \\
\hline $\begin{array}{l}\text { Middle } \\
\text { Region }\end{array}$ & 0.429 & 0.057 & 1.71 \\
\hline $\begin{array}{l}\text { Elevated } \\
\text { Region }\end{array}$ & 0.555 & 0.057 & 2.21 \\
\hline
\end{tabular}




\section{CONCLUSION}

The background nuclear radiation in the atmosphere have been measured in specific locations such as the ground region, middle region, and elevated region in Idanre hill in Ondo state using the Nuclear Rad*Scanner. The results obtained from this research work has shown that the mean outdoor effective dose equivalent $0.46 \mathrm{mSv}$ $\mathrm{y}^{-1}$ is lower than the $1 \mathrm{mSv} \mathrm{y}^{-1}$ limit recommended by the National Council on Radiation Protection (NCRP) and International Commission on Radiological Protection(ICRP) for the general public. This implies that there is little or no significant health risk due to radiation in the area. Nevertheless, the value obtained is about six times greater than the world average value of $0.07 \mathrm{mSv} \quad \mathrm{y}^{-1}$ by UNSCEAR (2008), and the value increases with altitude, which is an indication of elevated radiation due to cosmos effect.

The values of the absorbed dose rates, annual effective dose equivalent and excess lifetime cancer risk are all above the world average values of $59 \mathrm{nGy} \mathrm{h}^{-1}, 0.07$ $\mathrm{mSv} \mathrm{y}^{-1}$ and $0.29 \times 10^{-3}$ respectively, is an indication that there is a possibility of an elevated cancer risk to the people at Idanre hill, with residents living closest to the elevated region at a higher risk than those living at the middle or the ground region.

\section{Acknowledgement: None}

\section{Conflict of Interest: None}

\section{Source of Funding: None}

\section{REFERENCES}

1. Ademola, A. K., Bello, A. K., \& Adejumobi, A. C. (2014). Determination of natural radioactivity and hazard in soil samples in and around gold mining area in Itagunmodi, south-western, Nigeria. Journal of Radiation research and applied sciences, 7(3), 249-255.
2. Balco, G., Stone, J. O., Lifton, N. A., \& Dunai, T. J. (2008). A complete and easily accessible means of calculating surface exposure ages or erosion rates from $10 \mathrm{Be}$ and 26Al measurements. Quaternary geochronology, 3(3), 174-195.

3. Balco, G. (2011). Contributions and unrealized potential contributions of cosmogenic-nuclide exposure dating to glacier chronology, 1990-2010. Quaternary Science Reviews, 30(1-2), 3-27.

4. Gosse, J. C., \& Phillips, F. M. (2001). Terrestrial in situ cosmogenic nuclides: theory and application. Quaternary Science Reviews, 20(14), 1475-1560.

5. International Commission on Radiological Protection (1990): Recommendations of ICRP 60, Annals of the ICRP, New York PERGAMON, Press 21.

6. ICRP 2007. "The 2007 Recommendations of the International Commission on Radiological Protection". Annals of the ICRP. ICRP publication 10337 (2-4). 2007. ISBN 978-0-7020-3048-2.

7. NCRP. 2009. Ionizing radiation exposure of the population of the United States. NCRP Report 160. Bethesda, MD: National Council on Radiation Protection and Measurements.

8. Oyeyemi, K. D., Aizebeokhai, A. P., Adagunodo, T. A., Olofinnade, O. M., Sanuade, O. A., \& Olaojo, A. A. (2017). Subsoil characterization using geoelectrical and geotechnical investigations: implications for foundation studies. International Journal of Civil Engineering and Technology, 8(10), 302-314.

9. Sharma, Shatendra (2008). Atomic and Nuclear Physics. Pearson Education India. p. 478. ISBN 978-81-317-1924-4.

10. United Nations Scientific Committee on the Effects of Atomic Radiation, (UNSCEAR2008), Report to the General Assembly, Vol. 1, Annex B.

How to cite this article: Ibikunle S. B., Ibikunle B. C., Akinmoju C. Estimation of cosmic effect on background nuclear radiation. International Journal of Research and Review. 2022; 9(3): 83-88. DOI: https://doi.org/10.52403/ijrr. 20220310 